\title{
Can capital income tax improve welfare in an incomplete market economy with a labor-leisure decision?
}

Medak Fell, Danijela

Source / Izvornik: Occasional Paper Series, 2007, 11, 1 - 17

Journal article, Published version

Rad u časopisu, Objavljena verzija rada (izdavačev PDF)

https://doi.org/10.3326/ops.30

Permanent link / Trajna poveznica: https://urn.nsk.hr/urn:nbn:hr:242:263347

Rights / Prava: Attribution-NonCommercial-NoDerivatives 4.0 International/ImenovanjeNekomercijalno-Bez prerada 4.0 međunarodna

Download date / Datum preuzimanja: 2023-04-26

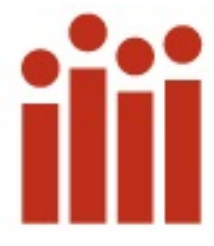

Repository / Repozitorij:

Institute of Public Finance Repository

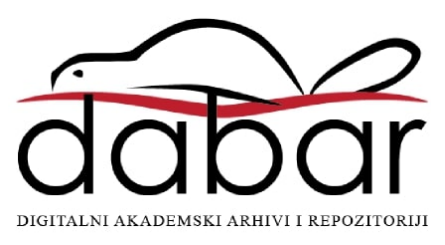




\section{CAN CAPITAL INCOME TAX IMPROVE WELFARE IN AN INCOMPLETE MARKET ECONOMY WITH A LABOR-LEISURE DECISION?}

Danijela Medak Fell

Occasional Paper No. 30

December 2006 


\title{
CAN CAPITAL INCOME TAX IMPROVE WELFARE IN AN INCOMPLETE MARKET: ECONOMY WITH A LABOR-LEISURE DECISION?*
}

\author{
Danijela Medak Fell \\ Institute of Public Finance \\ mfell@ijf.hr
}

\begin{abstract}
This paper is a quantitative exercise in the economic analysis of optimal fiscal policy. We look at an incomplete market economy where agents face idiosyncratic labor productivity shocks and borrowing constraints. We find the steady state equilibrium of this economy and then analyze the effect of a government policy introducing a capital income tax and redistributing the proceeds of tax collection back to the agents in the form of a labor subsidy. We find that this type of policy can indeed improve the welfare of the economy, but its quantitative effect is small. We thus conclude that using capital income tax as fiscal policy instrument is not an effective way to cure the problem of market incompleteness.
\end{abstract}

JEL Classification: E62

Keywords: optimal fiscal policy, incomplete markets, precautionary saving

* This article is published in Croatian in the journal "Financial Theory and Practice", 30(1), 2006, pp. 67-79, and is downloadable in Croatian from: http://www.ijf.hr/FTP/2006/1/medak-fell.pdf, and also in English from: http://www.ijf.hr/eng/FTP/2006/1/medak-fell.pdf 


\section{TABLE OF CONTENTS}

1. Introduction 5

2. The model economy 6

2.1 Consumers 6

2.2 Firms 6

$\begin{array}{ll}2.3 \text { Market arrangements } & 7\end{array}$

2.4 Individual decision problem $\quad 7$

2.5 Equilibrium 8

2.6 Introduction of taxes 9

3. Calibration and computation 9

4. Results 10

5. Conclusion 13

References 14 


\title{
CAN CAPITAL INCOME TAX IMPROVE WELFARE IN AN INCOMPLETE MARKET: ECONOMY WITH A LABOR-LEISURE DECISION?
}

\author{
Danijela Medak Fell
}

\section{INTRODUCTION}

Optimal taxation is an area in economics that always produces heated debates. The standard theory calls for smooth labor taxes and zero capital income tax, ${ }^{1}$ a rather unpopular result from the perspective of political economy. Recent advances in this strand of literature have been made in incomplete market, heterogeneous agents models where Aiyagari (1995) showed that the optimal capital income tax rate is strictly positive. The reason for this result is that in an incomplete market economy where agents face uninsurable idiosyncratic labor productivity shocks and borrowing constraints, they tend to overaccumulate assets in the form of precautionary savings - as a means to buffer labor income volatility and smooth consumption - agents amass capital stock and try to self-insure.

In the introduction to their recent paper, Braun and Uhlig (2000) pose an interesting question: is it possible to improve welfare by increasing capital income tax, even if we are to discard the collected tax revenue? Their somewhat surprising answer is yes! Following Aiyagari, and modeling the economy in such a way that there is no redistribution of taxes, they show that increasing the tax rate in such an economy can be welfare-improving. In other words, Aiyagari's original result is not the consequence of the redistribution of taxes, but rather of moving closer to the level of capital of the complete market economy, as described by the modified golden rule.

In this paper, we wanted to extend this result to an environment in which agents not only care about their consumption profile, but also about their leisure time, and then see whether this welfare-improving result still hold. Including leisure in the utility function reduces the welfare impact of a bad productivity shock as agents not working are able to enjoy more leisure time. Therefore, the resulting need for the accumulation of capital as a self-insurance device is lower than in an economy without a labor-leisure decision and the tax effect could be less pronounced or could even vanish. In addition, in our model we let the government redistribute the collected taxes and use them to grant labor subsidies, rewarding the effort of the workers and increasing incentives to work. We find that with our parameterization welfare still improves, but as expected, by a smaller margin than that found in Braun and Uhlig.

In modeling the economy, we follow the approach by Braun and Uhlig and consider only steady state equilibria, ignoring the transition effects of changing the tax rate, which could very well be welfareoffsetting. ${ }^{2}$ In section 2 we describe the model economy: the agents, their preferences, production sector and financial markets, and present the individual decision problem and the steady state equilibrium. Section 3 explains the calibration of the model and the computational procedure needed to

\footnotetext{
** The author thanks Francesco Obiols-Homs and Emiliano Carlucci for help and useful advice, and the anonymous reviewers for constructive proposals for the improvement of the paper, while taking full responsibility for any errors.

1 See Chamley (1986) for this result.
} 
reach the equilibrium, while section 4 presents the results. First we give an exhaustive description of the benchmark economy and then present a comparative study for different capital income tax rates. The last section provides conclusions.

\section{THE MODEL ECONOMY}

Time is discrete, $t=1,2, \ldots$ and the economy is the standard growth economy with production. We compare only steady states. The first three subsections describe our model economy: consumers and their preferences, producers and their technology, and the characteristics of the financial market. In subsection 2.4 we state the individual decision problem, the next subsection presents the formal definition of the steady state equilibrium, while the last subsection explains the mechanics of capital income tax introduction.

\subsection{Consumers}

The economy consists of a continuum of infinitely-lived agents with names in the unit interval, $i \in[0,1]$. All agents have identical preferences, defined over individual consumption $c_{t}$ and leisure $l_{t}$, and given by the following total utility function:

$$
U_{i}=E_{0}\left\{\sum_{t=0}^{\infty} \beta^{t} u\left(c_{i, t}, l_{i, t}\right)\right\},
$$

where $\beta \in(0,1)$ is the discount factor reflecting agents' impatience towards the future, $u(\cdot): R_{+}^{2} \rightarrow R$ is the period utility function and $E$ is the expectation operator. We assume a utility function that satisfies all the standard properties, i.e., one that is time separable, homothetic, continuous, differentiable, bounded, strictly increasing, strictly concave and that satisfies the Inada conditions. ${ }^{3}$

All agents are ex ante identical. However, in each time period they receive an idiosyncratic random labor productivity shock $\psi \in \Psi$ that makes them heterogeneous ex post. The labor productivity shock evolves according to the first order finite-state Markov process which is assumed to be identical and independent across agents. The probability that, given the state of today's of productivity shock $\psi$, tomorrow's shock will be $\psi^{\prime}$ is given by a transition function $\pi\left(\psi^{\prime} \mid \psi\right)$ which satisfies $\sum_{\psi^{\prime}} \pi\left(\psi^{\prime} \mid \psi\right)=1 \quad \forall \psi \in \Psi$ and $\pi\left(\psi^{\prime} \mid \psi\right)>0 \forall \psi, \psi^{\prime} \in \Psi$. We also assume that idiosyncratic shocks cancel out so that there is no uncertainty on the level of the aggregate labor endowment.

\subsection{Firms}

There is a competitive sector of profit-maximizing firms hiring labor $H_{t}$ and renting capital $K_{t}$ to produce output with the following neoclassical production function:

2 To learn more about transition problematics, one should look at Garcia et al. (1995).

3 These technical assumptions incorporate our standard economic beliefs about the characteristics of individual utility functions (more is better, but at a diminishing rate...), guarantee a unique and an interior solution to the maximization problem and facilitate its computation and analysis. 


$$
Y_{t}=F\left(K_{t}, H_{t}\right)
$$

The production technology is assumed to satisfy constant returns to scale, continuity, differentiability, strict monotonicity and convexity assumptions. In addition, we also impose the Inada and no-free-lunch conditions.

Firms face a static, period by period problem and solve the following maximization problem:

$$
\max _{K_{t}, H_{t}} F\left(K_{t}, H_{t}\right)-r_{t} K_{t}-w_{t} H_{t},
$$

where $r_{t}$ is the return on capital and $w_{t}$ is the wage rate, both in terms of period $t$ consumption. Since the sector is competitive and thus profits are zero, in the equilibrium the prices of capital and labor will be given by their marginal return:

$$
\begin{gathered}
r_{t}=\frac{\partial F\left(K_{t}, H_{t}\right)}{\partial K_{t}}, \\
w_{t}=\frac{\partial F\left(K_{t}, H_{t}\right)}{\partial H_{t}} .
\end{gathered}
$$

Capital depreciates at an exogenously given rate $\delta \in[0,1]$. Aggregate capital $K_{t}$ results from the aggregation of all assets across agents, while aggregate labor $H_{t}$ is the aggregate across individual labor supply. Since there is no aggregate uncertainty, prices in the steady state will remain constant and from now on we suppress the time index.

\subsection{Market arrangements}

Financial markets in this economy have two types of imperfection. One is that agents are not allowed to hold negative assets, i.e., they face a tight borrowing constraint $b \geq 0$. The second feature is the absence of insurance markets in which agents would be able to insure against their idiosyncratic shock $\psi{ }^{4}$ As a result, the only way to smooth their consumption given their volatile income stream is through self-insurance: they will save in the only available asset - the physical capital.

\subsection{Individual decision problem}

In the beginning, at period $t=0$, all agents are endowed with an initial amount of capital $k_{i, 0}$. They derive their period $t$ income from working $h_{i, t} \in[0,1]$ normalized hours (for which they receive $w$ ), and from renting their capital stock to the firms (for which they receive $R=1+r-\delta$ ). In any given period they can receive a beneficial labor productivity shock and be fully productive, i.e., $\psi=1$, or they can end up with a bad shock and be completely unproductive, $\psi=0$. Then, they use their period $t$ income to buy consumption goods or to amass new capital stock, where negative investment is also permitted

4 In this paper we simply impose the absence of insurance markets on agents, even though this market structure can be explicitly accounted for using market imperfections such as moral hazard, adverse selection or limited enforceability problems which limit perfect risk sharing among agents. 
(the agents can resell their capital holdings in order to buy consumption). ${ }^{5}$

Now, the agents' problem is choosing the optimal sequences of consumption, leisure and capital savings $\left\{c_{t}, l_{t}, k_{t+1}\right\}_{t=0}^{\infty}$ that maximize their expected present discounted lifetime utility given their budget constraint, nonnegativity constraint on consumption, borrowing constraint on capital and feasibility constraint on the labor-leisure choice. ${ }^{6}$ Technically, we write this problem as a sequential dynamic program (SP):

$$
\begin{aligned}
\max _{\left\{c_{t}, l_{t}, k_{t+1}\right\}_{t=0}^{\infty}} E_{0}\left\{\sum_{t=0}^{\infty} \beta^{t} u\left(c_{t}, l_{t}\right)\right\} \\
\text { s.t. } c_{t}+k_{t+1} \leq w h_{t} \psi_{t}+R k_{t}, \\
c_{t} \geq 0, k_{t+1} \geq b, \\
l_{t}+h_{t}=1 .
\end{aligned}
$$

Given our assumptions on the utility function, from the Contraction Mapping Theorem as explained in Stokey et al. (1989) we know that this problem can be rewritten in the recursive form of the Bellman equation whose solution is the same as the solution to our original SP problem, and has the additional advantage that it is computationally easier to reach. We call this problem the functional equation program (FE):

$$
\begin{aligned}
v(k, \psi) & =\max _{c, l, k^{\prime}}\left\{u(c, l)+\beta \operatorname{Ev}\left(k^{\prime}, \psi^{\prime}\right)\right\} \\
\text { s.t. } c+k^{\prime} & \leq w h \psi+R k, \\
c & \geq 0, k^{\prime} \geq b, \\
l+h & =1,
\end{aligned}
$$

where $v(k, \psi)$ denotes the value function given today's capital and productivity shock. The solution to the FE program consists of the optimal policy functions for consumption today $c=c(k, \psi)$, the workleisure decision today $l=l(k, \psi)$ and the capital to save for tomorrow $k^{\prime}=k(k, \psi)$, all given state variables $\{k, \psi\}$.

\subsection{Equilibrium}

The steady state recursive equilibrium for this economy is the value function $v(k, \psi)$, the set of optimal policy functions $\{c, l, k\}$ and the distribution of households such that:

1) given factor prices $\{w, R\}$, the policy functions $\{c, l, k\}$ solve the consumers' decision problem

For recent references concerning the endogenous incomplete markets theory see Alvarez and Jermann (2000).

5 Note that this only implies that investment is reversible and capital can be sold and exchanged for consumption in any period. However, this does not imply agent can have negative assets, i.e., accumulate debt.

6 We suppress the individual subscript since all agents are ex ante identical and will follow the same optimal decision rule. 
described in the last section,

2) given factor prices $\{w, R\}$, firms maximize their profits,

3) all markets clear - after aggregation across individual variables, given the steady state distribution of agents, the feasibility constraint must hold:

$$
\begin{aligned}
K & =\int_{0}^{1} k d i, \\
H & =\int_{0}^{1} h d i, \\
C+K^{\prime} & =F(K, H)+(1-\delta) K,
\end{aligned}
$$

4) the distribution of households across assets is stationary.

From Huggett (1993) we also know that this equilibrium is characterized by $\beta R<1$, i.e., the market interest rate is lower then the subjective preference rate.

\subsection{Introduction of taxes}

After finding the equilibrium of this incomplete markets economy with heterogeneous agents and borrowing constraints, we assess the effect of introducing capital income taxation which is then redistributed in the form of a labor subsidy proportional to the hours of work. To do this, we let $\tau^{h}=\varepsilon \tau^{k} \frac{K}{H}$ be the total amount of capital income tax that is redistributed to labor, where $\varepsilon \in[0,1)$ denotes the efficiency loss by having the government transfer taxes from capital to labor. With these assumptions, labor income is now given by $\left(w+\tau^{h}\right) h \psi$ and this is the expression we now plug into the above budget constraint.

\section{CALIBRATION AND COMPUTATION}

We choose to work with the constant relative risk aversion (CRRA) class of utility functions of the form

$$
E_{0} \sum_{t=1}^{\infty} \beta^{t} \frac{\left(\left[\eta c_{t}^{-\gamma}+(1-\eta) l_{t}^{-\gamma}\right]^{-1 / \gamma}\right)^{1-\sigma}-1}{1-\sigma}
$$

where $\beta, \eta, \gamma$ and $\sigma$ are preference parameters. We set the time discount factor $\beta=0.99$, the coefficient of relative risk aversion $\sigma=1.001$, the weight consumers place on consumption $\eta=0.33$ and the adjustment factor $\gamma=0.0001$. These are all standard values used in related literature, based on microeconomic and macroeconomic observations and consistent with stylized facts observed in the data. Technology is Cobb-Douglas $F\left(K_{t}, H_{t}\right)=T K_{t}^{\alpha} H_{t}^{1-\alpha}$ where $T=0.5$ is a scale parameter and $\alpha=0.36$ stands for the capital income share in the GDP. We assume the time period to be the quarter of a year, and therefore set the depreciation rate of capital at $\delta=0.025$. The set of labor productivity shocks is $\Psi=\{0,1\}$ and we set both shocks to be equally likely, $\pi\left(\psi^{\prime} \mid \psi\right)=0.5$. The borrowing limit $b$ is fixed at 1 unit. 
The computing procedure used to find the equilibrium consists of three steps:

1) Guess the equilibrium capital-labor ratio, or equivalently the equilibrium prices $\{r, w\}$ such that $\beta R<1$. As a good initial guess, we can use either the results from related models already investigated in the literature, or we can start somewhere close to the complete market result (which can be found analytically) and work from there.

2) Given this guess, compute the optimal decision rules over a capital grid for each of the two possible labor productivity shocks.

3) Simulate the shocks and the resulting behavior of the model economy for a long time period and check if the resulting capital-labor ratio is the same as the guess. If it is, the equilibrium has been found. If not, update the guess using simple economic intuition ${ }^{7}$ and repeat the procedure until approximate market clearing is obtained.

We designed the grid for capital to consist of 1500 points, where the initial points are closer together and the grid is finer to control for the accuracy of the approximated policy rules. Between grid points we used linear approximation so that the algorithm approximates the policy functions, given the initial guess for the equilibrium prices $\{r, w\}$, by piecewise linear functions. The accuracy criterion we used for the iteration on policy functions is $10 e^{-5}$, while market clearing was achieved with the precision of 0.005 units of zero. We simulate the time series for 300 thousand periods in order to insure ergodicity. Additionally, we kept constant the random number generator seed to achieve consistent results for all tested models.

When we introduce capital income tax $\tau^{k}$ and labor subsidy $\tau^{h}$, we test for $\tau^{k}=\{0.01,0.05,0.10\}$ and compare the results with the benchmark model without taxes. ${ }^{8}$ We also assume a very efficient government that succeeds in redistributing $\varepsilon=99 \%$ of its capital income taxes.

The Matlab file containing the algorithm for this computational procedure is available upon request.

\section{RESULTS}

First we deal with optimal decision rules for consumption, capital savings and leisure as shown in Figure 1. Notice that all policy rules behave in the same way as described in Huggett (1993), i.e., they inherit the monotonicity and convexity properties of the return function, and the optimal level of tomorrow's consumption, leisure time or saving, given the capital level today, is always higher when the agent experiences a positive productivity shock than when he experiences a negative one. The only exception is the policy rule for leisure: note that the agent will always choose not to work if he is hit with a bad productivity shock, as this is the corner solution to his maximization problem. ${ }^{9}$

Next, notice that when we compare the optimal levels for a good and a bad shock the difference is bigger for low levels of capital, while it almost disappears for high levels of capital. This is especially

\footnotetext{
7 If the initial guess created excess demand, it should be increased, while if it resulted in excess supply, it should be decreased.

8 The reason we don't test for higher levels of tax rates is that they pushed the interest rate towards its complete market level, and for the given level of unemployment uncertainty, we encountered numerical problems in our algorithm.

9 This is the reason why Figure 1. shows only the interesting case of the good productivity shock.
} 
pronounced in the consumption policy rule. This result suggests that poor agents are more vulnerable to bad shocks as they do not hold sufficient asset holdings to buffer themselves against a temporary low productivity level, but instead they are forced to hold back on their consumption patterns. Further analysis reveals that all agents optimally decide to save a large fraction of their current capital for the future (the optimal policy rule is close to the $45^{\circ}$ line), not distinguishing very much between the good and the bad shock case. This result follows directly from our assumptions on the distribution of shocks: the risk of becoming poor is very high, so all agents try very hard to avoid this state and amass capital as quickly as they can.

The last thing to notice is that even very rich agents will optimally choose to work when hit by a good shock, though a lot less than their poorer counterparts. The reason that they work even when very rich is essentially the same as before: the probability of going back to poverty is very high and there is still some value in working when productivity is good. However, as the agent gets rich, more of his income comes from his asset holding, and less from working, so it is economically intuitive that he should start working less and enjoying his leisure time more. Finally, the stationary distribution of agents in the model economy with respect to their capital holdings is also given in Figure 1.

Figure 1 Optimal policy rules and the equilibrium distribution of capital
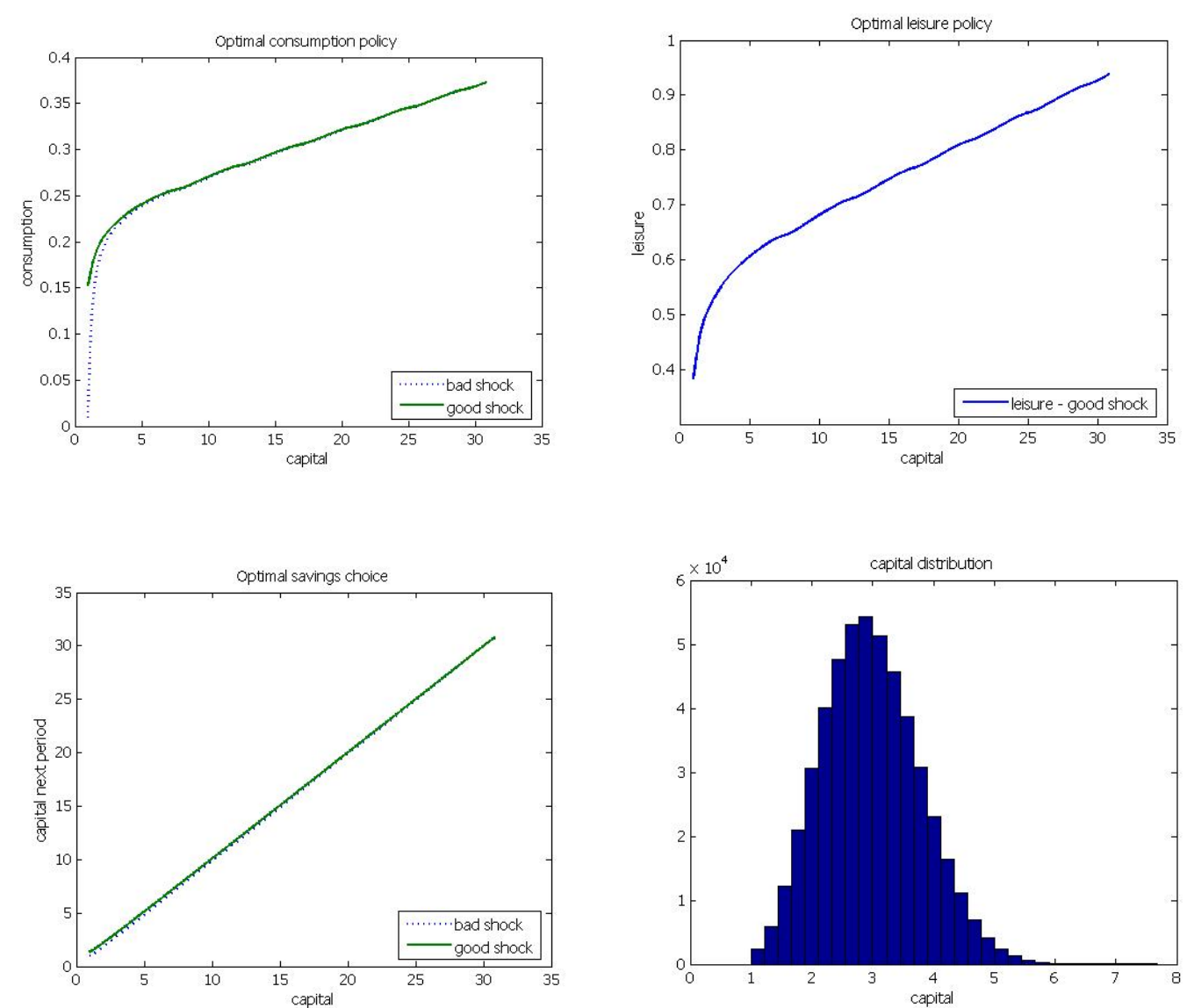

Source: author's calculation

Next, we report the equilibrium objects for the benchmark model economy and the economies in which we introduced capital income taxation. Table 1 shows the equilibrium prices, the capital-labor ratio and average welfare. Notice that the introduction of the tax rate pushes the equilibrium level of capital-labor 
ratio towards its complete market level of 12.8618 , and the interest rate respectively towards $3.51 \%$. This means that the increase in the capital income tax effectively acts to reduce agents' asset holdings (as capital income yields less after-tax income) and shifts agents' interest toward more work effort and to increasing the share of labor income (as this is not taxed). With smaller savings, capital becomes scarcer and the interest on it goes up, while labor supply is more abundant and the equilibrium wage rate decreases. The last rows of Table 1 confirms the hypothesis of this paper: the increase of the capital income tax rate leads to higher average (individual) welfare, ${ }^{10}$ and a closer look at Table 2 reveals that this increase is quantitatively very modest. The interpretation is as follows: because agents do not need to save a lot of excess capital to safeguard against bad shocks, they enjoy higher consumption in the equilibrium of our model economy, which increases their welfare. However, they compensate for lower capital levels by working longer hours, sacrificing their leisure time and thus reducing welfare. The overall effect on welfare is still positive, but low. For example, the highest capital income tax of $10 \%$ manages to reduce the precautionary savings level to just $1 \%$, but the resulting increase in welfare is just $0,59 \%$.

Therefore, we can conclude that even though analytically it seemed there was room for government intervention in the light of market imperfections, quantitatively this result is much less convincing. As expected, it is much more advisable to try to correct market failures by addressing the issue directly at the root of the problem (in our case, uninsurable productivity risk and borrowing constraints), and not by introducing a different type of market distortion that inhibits the free functioning of the market (capital income tax). Additionally, remember that in our model economy we assumed a very high degree of government efficiency in redistributing taxes, which is an assumption somewhat at odds with the situation in the real world.

Table 1 Equilibrium objects

\begin{tabular}{|l|r|r|r|r|}
\hline & Benchmark & Tax rate & Tax rate & Tax rate \\
\hline & Economy & $\mathbf{1 \%}$ & $\mathbf{5 \%}$ & $\mathbf{1 0 \%}$ \\
\hline Interest rate & 0.034759 & 0.034853 & 0.034867 & 0.034879 \\
\hline Wage rate & 0.80703 & 0.80581 & 0.80563 & 0.80547 \\
\hline Capital-labor ratio & 13.0602 & 13.0079 & 13.0022 & 12.9908 \\
\hline Mean welfare & -0.7166 & -0.7164 & -0.7152 & -0.7124 \\
\hline
\end{tabular}

Source: author's calculation

Table 2: Percentage changes

\begin{tabular}{|l|r|r|r|r|}
\hline & Benchmark & Tax rate & Tax rate & Tax rate \\
\hline & Economy & $\mathbf{1 \%}$ & $\mathbf{5 \%}$ & $\mathbf{1 0 \%}$ \\
\hline Precautionary savings & $1.54 \%$ & $1.12 \%$ & $1.05 \%$ & $1.00 \%$ \\
\hline Mean welfare & - & $0.03 \%$ & $0.20 \%$ & $0.59 \%$ \\
\hline
\end{tabular}

Source: author's calculation

10 Note that the negative value for welfare is just a question of mathematical normalization. 


\section{CONCLUSION}

In this paper we tested the validity of an analytical result on optimal fiscal policy and investigated its quantitative implications. We looked at an incomplete market economy where agents face idiosyncratic labor productivity shocks and borrowing constraints and then analyzed the effects of introducing a fiscal policy that taxes capital income and redistributes the collected taxes back to the agents in the form of a labor subsidy. We found that in our model economy this fiscal policy is desirable and that it indeed improves the welfare of the economy. However, this improvement is of such a small extent as largely to weaken any arguments in favor of implementing this type of policy.

A possible extension of this paper is a sensitivity analysis where the results are tested for their robustness to the changes in parameters' values. Given that we used a very standard parameterization (adjusted to mimic the American stylized facts of growth), this exercise in itself would not be scientifically rewarding. However, if we are able to convincingly argue or show that there are reasons to believe the parameters to be of significantly different values, the case for sensitivity analysis is stronger. This is why our proposal for further research is to calibrate the model to fit Croatian data. If anything, this effort would provide a first attempt to quantify the calibration parameters for the Croatian economy that could subsequently be used in any general equilibrium model designed to address Croatian economic issues. Additionally, we could also check whether the quantitative implications of the present model change significantly and use this finding for a possible fiscal policy recommendation. However, due to the lack of a longer time series and other data, this represents a project that is sufficiently challenging as to require further research. 


\section{REFERENCES}

Aiyagari, S. R., 1995. Optimal capital income taxation with incomplete markets, borrowing constraints and constant discounting. Journal of Political Economy 103, 1158-1175.

Alvarez, F. and Jermann, U., 2000. Efficiency, equilibrium and asset pricing with risk of default. Econometrica 68, 775-798.

Braun, T. and Uhlig, H., 2000. The welfare effects of a wasted capital income tax increase in the presence of uninsurable idiosyncratic risk. Working paper, Center for Economic Research, Tilburg University.

Chamley, C., 1986. Optimal taxation of capital income in general equilibrium with infinite lives. Econometrica 54, 607-22.

Garcia Milá, T., Marcet, A. and Ventura, E., 1995. Supply Side Interventions and Redistribution. UPF Working Paper Ref. 115.

Huggett, M., 1993. The risk free rate in heterogeneous-agents, incomplete insurance economies. Journal of Economic Dynamics and Control 17(5/6), 953-970.

Stokey, N. L., Lucas, R. E., Jr. and Prescott, E. C., 1989. Recursive Methods in Economic Dynamics. Cambridge, Mass.:Harvard University Press. 
INSTITUTE OF PUBLIC FINANCE - OCCASIONAL PAPER SERIES

\begin{tabular}{|c|c|}
\hline No. 1 & $\begin{array}{l}\text { State Intervention for Growth Promotion in Market Economies } \\
\text { Marina Kesner Škreb, January } 1997\end{array}$ \\
\hline No. 2 & $\begin{array}{l}\text { Estimate of Revenues from the Value Added Tax in the Republic of Croatia } \\
\text { Danijela Kuliš and Žarko Miljenović, October } 1997\end{array}$ \\
\hline No. 3 & $\begin{array}{l}\text { The Unofficial Economy in Croatia: Causes, Size and Consequences } \\
\text { Ivo Bićanić and Katarina Ott, November } 1997\end{array}$ \\
\hline No. 4 & $\begin{array}{l}\text { Price Effects of VAT Introduction in Croatia } \\
\text { Martina Dalić, December } 1997\end{array}$ \\
\hline No. 5 & $\begin{array}{l}\text { Tax Administration Reform in Transition: The Case of Croatia } \\
\text { Katarina Ott, April } 1998\end{array}$ \\
\hline No. 6 & $\begin{array}{l}\text { The Present Sate of the Croatian Public Debt } \\
\text { Zoran Bubaš, December } 1998\end{array}$ \\
\hline No. 7 & $\begin{array}{l}\text { Public Investment in Croatia } \\
\text { Katarina Ott and Anto Bajo, March } 1999 .\end{array}$ \\
\hline No. 8 & $\begin{array}{l}\text { Welfare Policy and Social Transfers in Croatia } \\
\text { Predrag Bejaković and Alastair McAuley, July } 1999\end{array}$ \\
\hline No. 9 & $\begin{array}{l}\text { Is Unofficial Economy a Source of Corruption? } \\
\text { Vedran Šošić and Michael Faulend, November } 1999\end{array}$ \\
\hline No. 10 & $\begin{array}{l}\text { Banking Sector Problems: Causes, Resolutions and Consequences } \\
\text { Ljubinko Jankov, March } 2000\end{array}$ \\
\hline No. 11 & $\begin{array}{l}\text { Toward a Long - Term Strategy of Economic Development of Croatia: Where to Begin, What to Do, and } \\
\text { How to Do It? } \\
\text { Dubravko Mihaljek, June } 2001\end{array}$ \\
\hline No. 12 & $\begin{array}{l}\text { The Underground Economy in Croatia } \\
\text { Katarina Ott, March } 2002\end{array}$ \\
\hline No. 13 & $\begin{array}{l}\text { An Estimate of the Extent of Tax Evasion in Croatia } \\
\text { Sanja Madžarević Šujster, April } 2002\end{array}$ \\
\hline No. 14 & $\begin{array}{l}\text { Opportunism, Institutions and Moral Costs: The Socio - Cultural Dimension of the Underground } \\
\text { Economy in Croatia } 1995 \text { - } 1999 \\
\text { Aleksandar Štulhofer and Ivan Rimac, April } 2002\end{array}$ \\
\hline No. 15 & $\begin{array}{l}\text { Dollarisation and the Underground Economy: Accidental Partners? } \\
\text { Vedran Šošić and Michael Faulend, April } 2002\end{array}$ \\
\hline No. 16 & $\begin{array}{l}\text { Decentralization in the Republic of Croatia - A City Budget in the Period from } 1996 \text { to } 2000 \\
\text { Mihaela Pitarević, March } 2003\end{array}$ \\
\hline No. 17 & $\begin{array}{l}\text { Inequality in Croatia in the Period from } 1973 \text { to } 1998 \\
\text { Danijeli Nestić, April } 2003\end{array}$ \\
\hline
\end{tabular}




\begin{tabular}{|c|c|}
\hline No. 18 & $\begin{array}{l}\text { State Aid to Enterprises in Croatia in } 2001 \\
\text { Marina Kesner-Škreb, Ivana Pleše and Mia Mikić, October } 2003\end{array}$ \\
\hline No. 19 & $\begin{array}{l}\text { The Role of Parliament in the Budgetary Process - The Example of } \\
\text { the Croatian Parliament } \\
\text { Vjekoslav Bratić, October } 2004\end{array}$ \\
\hline No. 20 & $\begin{array}{l}\text { Local Government Unit Borrowing in Croatia: Opportunities and Constraints } \\
\text { Anto Bajo, October } 2004\end{array}$ \\
\hline No. 21 & $\begin{array}{l}\text { The Costs of Customs Compliance in Croatia in } 2001 \\
\text { Mihaela Bronić, November } 2004\end{array}$ \\
\hline No. 22 & $\begin{array}{l}\text { Tax Compliance Cost of Small Business in Croatia } \\
\text { Helena Blažić, November } 2004\end{array}$ \\
\hline No. 23 & $\begin{array}{l}\text { The Compliance Costs of Excise Duties in Croatia } \\
\text { Danijela Kuliš, November } 2004\end{array}$ \\
\hline No. 24 & $\begin{array}{l}\text { The Administrative Costs of Taxation and Customs Clearing in Croatia, 1999-2001 } \\
\text { Vjekoslav Bratić and Mihaela Bronić, November } 2004\end{array}$ \\
\hline No. 25 & $\begin{array}{l}\text { Fiscal Decentralization in Croatia: Problems of Fiscal Equalization } \\
\text { Anto Bajo and Mihaela Bronić, May } 2005\end{array}$ \\
\hline No. 26 & $\begin{array}{l}\text { Income Distribution in Croatia: What Do the Household Budget Survey Data Tell Us? } \\
\text { Danijel Nestić, June } 2005\end{array}$ \\
\hline No. 27 & $\begin{array}{l}\text { Impact of Foreign Direct Investment on Croatian Manufacturing Exports } \\
\text { Goran Vukšić, June } 2006\end{array}$ \\
\hline No. 28 & $\begin{array}{l}\text { Managing the Cash and Liquidity of the Croatian Budget } \\
\text { Anto Bajo, June } 2006\end{array}$ \\
\hline No. 29 & $\begin{array}{l}\text { The Quality of Governance and Economic Growth in Croatia } \\
\text { Marijana Bađun, June } 2006\end{array}$ \\
\hline No. 30 & $\begin{array}{l}\text { Can Capital Income Tax Improve Welfare in an Incomplete Market: Economy with Labor-Leisure } \\
\text { Decision? } \\
\text { Danijela Medak Fell, December } 2006\end{array}$ \\
\hline
\end{tabular}




\section{ABOUT THE INSTITUTE OF PUBLIC FINANCE}

The Institute of Public Finance (Zagreb, Croatia) founded in 1970, is a public institution dealing with research in the field of public sector economics, but also in applied and theoretical research on broader set of economic topics such as economic growth and development, role of institutions, transition to the market economy and EU integration. The empirical analysis is preferably related, but not limited, to experience of countries in Central and Eastern Europe and Southeast Europe.

\section{SELECTED LIST OF PUBLICATION (in English)}

\section{Serial publications}

- Financial Theory and Practice

- Occasional Paper Series

- Newsletter

\section{Books}

- Croatian Accession to the European Union: Facing the Challenges of Negotiations, editor Katarina Ott, 2005.

- The competitiveness of Croatia's human resources, editors Predrag Bejaković and Joseph Lowther, 2004.

- Croatian Accession to the European Union: Institutional Challenges, editor Katarina Ott, 2004.

- The Croatian Tax System, editor Mirjana Jerković, 2003.

- Croatian Accession to the European Union: Economic and Legal Challenges, editor Katarina Ott, 2003.

- The Citizen's Guide to Taxation, Marina Kesner-Škreb and Danijela Kuliš, 2001, (updated online).

- A Citizen's Guide to the Budget, editor Katarina Ott, 2000.

For further insight in our publications and ordering information please visit:

http://www.ijf.hr/eng/index.html. 